\title{
Assisted phytoextraction of heavy metals: compost and Trichoderma effects on giant reed (Arundo donax L.) uptake and soil $\mathrm{N}$-cycle microflora
}

\author{
Nunzio Fiorentino, Massimo Fagnano, Paola Adamo, Adriana Impagliazzo, Mauro Mori, \\ Olimpia Pepe, Valeria Ventorino, Astolfo Zoina
}

Dipartimento di Agraria, Università di Napoli Federico II, Portici (NA), Italy

\begin{abstract}
Little information is available as to the real effectiveness of the phytoextraction remediation technique, since laboratory experiments are still the most common way in which this is measured. Given this, an experiment on a cadmium-polluted soil was carried out in open field conditions in Southern Italy with the aim of assessing the growth and the phytoextraction potential of giant reed (Arundo donax L). Compost fertilisation and Trichoderma harzianum A6 inoculations were used to verify the possibility of increasing the metal uptake of the crop. Biomass yield of giant reed in the first growth season (average 12.8 $\mathrm{Mg} \mathrm{ha}^{-1}$ ) was not affected by the Cd concentration in the soil and this increased significantly with compost fertilisation (13.8 $\left.\mathrm{Mg} \mathrm{ha}^{-1}\right)$. Both compost fertilisation and T. harzianum inoculation increased cadmium uptake and translocation in leaves. Nitrifying bacteria was shown to be a useful tool to biomonitor soil quality. These results proved the suitability of the giant reed for assisted-phytoremedation with the use of compost fertilisation and T. harzianum.
\end{abstract}

\section{Introduction}

The extent of soil pollution by potentially toxic elements (PTE) in

Correspondence: Massimo Fagnano, Università di Napoli Federico II, via Università 100, 80055 Portici (NA), Italy. Tel. +39.081 .2539129 .

E-mail: massimo.fagnano@unina.it

Key words: cadmium, inoculation, mycorrhiza, phytoremediation, potentially toxic elements.

Acknowledgements: we would like to thank Prof. Matteo Lorito for kindly providing the Trichoderma harzianum A6 strain and for fruitful discussion and suggestions. We are also grateful to Prof. Alessandro Piccolo for offering the resources of his laboratory and for fruitful discussion and suggestions.

Received for publication: 19 June 2013.

Revision received: 3 October 2013.

Accepted for publication: 4 October 2013.

(C) Copyright N. Fiorentino et al., 2013

Licensee PAGEPress, Italy

Italian Journal of Agronomy 2013; 8:e29

doi:10.4081/ija.2013.e29

This article is distributed under the terms of the Creative Commons Attribution Noncommercial License (by-nc 3.0) which permits any noncommercial use, distribution, and reproduction in any medium, provided the original author(s) and source are credited. industrialised areas is well documented (Glass, 1998; Black, 1999) and represents an important environmental concern due to their potential accumulation in the food chain. Human activities such as industrial plants, mining, road transport and the unwise application of sewage sludges, fertilisers and pesticides to agricultural soils are recognised to be the main sources of PTE pollution (do Nascimento et al., 2006; Lado et al., 2008). A large number of methods are available to remediate soils, such as soil washing with synthetic surfactants. However, these are extremely expensive, such that a large number of sites remain contaminated (Ensley, 2000). Moreover, ex situ soil reclamation techniques lead to a big reduction in soil fertility due to the soil disturbance and to the toxicity of synthetic surfactants. Soil washing with humic substances extracted from composted organic matter or from geochemical deposits represents a reliable alternative (Conte $e t$ al., 2005) and phytoextraction is a valuable complementary technique. It is low cost and environmentally safe (Wu et al., 2006) and is able to both remove heavy metal pollutants from the soil and to offer important economic and agronomic advantages (Mattina et al., 2003). It involves the utilisation of plants to remove heavy metals from soil and concentrate them in the biomass. For years now, metal hyperaccumulating plants such as Alyssum murale, Berkheya coddii, Brassica juncea and Thlaspi caerulescens have been considered the most suitable tool to decontaminate metal-polluted soils, but the low biomass growth and scarce ability to accumulate various different metals together (Krämer, 2005) have discouraged their inclusion in commercial phytoextraction protocols (do Nascimento et al., 2006).

Consequently, the current trend is to use fast-growing high biomass crops that accumulate moderate levels of metals in their shoots (Hernández-Allica et al., 2008), since a greater aboveground biomass yield can more than compensate for the lower PTE concentration in plant tissues (Ebbs and Kochian, 1998).

From this point of view, the most suitable species for phytoextraction have to be characterised by wide-ranging tolerance to pollutants, high biomass yield and easy cropping technique (Chaney et al., 2000). These characteristics are perfectly coupled in giant reed (Arundo donax L.), a rhizomatous perennial grass, native to southeast Europe, that lives in a wide range of different ecological conditions (Papazoglou, 2007). Giant reed was shown to be able to grow vigorously in soils with high cadmium (Cd) and nickel (Ni) content (McGarth et al., 2006; Chary et al., 2008), or in contaminated soils with high levels of arsenic (As), Cd and lead (Pb) (Guo and Miao, 2010), gaining a total biomass yield of $30-40 \mathrm{Mg} \mathrm{ha}^{-1}$ without any agronomic input (Angelini et al., 2005; Williams and Biswas, 2010).

Due to its fast growth and high cellulose content, giant reed is considered one of the most promising energy crops for marginal lands (Nassi, 2011) and its culms represent an interesting source of cellulose for producing paper (Ververis et al., 2004), second generation ethanol, bio-diesel or biopolymers (Williams and Biswas, 2010; Pirozzi et al., 2010). Furthermore, the residual lignin content (15-20\%) (Ververis et al., 2004) could be of interest for compost production or other high-value materials such as lignin-based resin coatings and 
composites (Piccolo et al., 1997; Park et al., 2008). If high levels of metals in the phytoextracting biomasses do not allow any other uses, the most environmentally-safe solution is the production of energy from combustion or pyro-gasification (Chen et al., 2004; Vervaeke et al., 2006; Lievens et al., 2008) followed by metal recovery from the molten fly ashes by using hydrometallurgical routes, such as the carried-inpulp method proposed by Alorro et al. (2008).

Since the long period for cleaning up is considered the real Achilles' heel of phytoextraction (Van Nevel et al., 2007), management techniques have been developed that can increase PTE availability to plants (Marchiol and Fellet, 2011) and to manipulate rhyzosphere plantmicrobe associations for a better uptake efficiency of roots (assisted phytoextraction). Synthetic chelates, such as ethylenediaminetetraacetic acid (EDTA), significantly increase plant ability to uptake heavy metals, but this technique is not practicable in open fields since the high environmental persistence could lead to metal leaching in the water table (Meers et al., 2005). On the contrary, many organic compounds such as low molecular organic acids (citric and gallic acids) are able to increase $\mathrm{Cd}$, zinc $(\mathrm{Zn})$, copper $(\mathrm{Cu})$ and $\mathrm{Ni}$ uptake from soil without environmental risks (do Nascimiento et al., 2006). In some cases, compost fertilisation could be a useful tool to increase metal availability due to the high capacity of metal complexation by humic substances (Clemente and Bernal, 2006; Bianchi et al., 2008), soil fertility due to the soil organic matter buildup (Piccolo et al., 2004; Fagnano et al., 2011), and functional microbial groups (Pepe et al., 2013). Moreover, the effect of exogenous organic matter is $\mathrm{pH}$ dependent, allowing an increase in metal availability in alkaline soils (Santibáñez et al., 2008; Fagnano et al., 2011) while this is reduced in low pH soils (Alvarenga et al., 2009; Fornes et al., 2009). Interesting results could also be achieved by modifying the microbe-plant association in rhizo-soil (Cao et al., 2008), since microbes play a key role in soil element cycling. Fungi are well known for their ability to detoxify PTE through passive and active uptake (Kapoor et al., 1999), valence transformation or precipitation (Zafar et al., 2007). Among these, Trichoderma spp., an avirulent, opportunistic plant symbiotic, has emerged thanks to its high detoxification potential (Harman et al., 2004; Vinale et al., 2009). Its high colonisation ability together with its action in promoting plant growth (Vinale et al., 2003) allowed a significant increase in heavy metal uptake in a wide range of plant species from willow (Adams et al., 2007) to oilseed rape (Brassica napus) (Wang et al., 2009).

The study of the mechanisms of assisted-phytoremediation is obviously plant-based, since the metal concentration in plant tissues is the emerging effect of metal bioavailability. Understanding of the processes taking place in the polluted soils by adding chelating agents or manipulating rhizosphere could be improved by measuring metal availability, but this approach is sometimes expensive in terms of time and money. Biomonitoring with soil microorganisms can integrate chemical analyses to assess soil quality, since microbial communities live in intimate contact with the soil microenvironment, and rapidly and sensitively respond to changes in the surrounding conditions (Hargreaves et al., 2003). PTE affect growth, morphology and metabolism of microorganisms in soils, through functional disturbance, protein denaturation or destruction of cell membranes (Leita et al., 1995). Microorganisms involved in the nitrogen cycle have been found to be particularly sensitive to PTE in field and in vitro experiments. The nitrification process is considered one of the most sensitive microbial assays since it can evaluate even small traces of metal toxicity (Broos et al., 2005). In fact, nitrifying bacteria are sensitive to inorganic compounds such as $\mathrm{Cd}$ (Hu et al., 2002; Chandran and Love, 2008), Ni, chromium (Cr), $\mathrm{Cu}$ and $\mathrm{Zn}$ (Cela and Sumner, 2002).

Little is known about the real effectiveness of phytoextraction with high biomass crops since laboratory experiments are still the most common way in which this is measured. (Van Nevel et al., 2007). In particular, the metal bioconcentration ability of giant reed has only been studied in controlled environments adopting soilless or in-pot cultivation (Mavrogianopoulos et al., 2002; Papazoglou, 2007; Mirza et al., 2010). Moreover, assisted-phytoextraction has never been studied with this plant.

In this study, we carried out an experiment on a heavy metal polluted soil in Southern Italy to assess the growth and phytoextraction potential of giant reed in open field conditions. Compost fertilisation and inoculation of rhizomes with Trichoderma harzianum strain A6 were also tested in order to evaluate a low cost technique for soil cleanup. The composition of total aerobic heterotrophic, ammonia and nitrite-oxidizing bacterial populations was estimated and the structure of a cultivable microbial population was also assessed to monitor the effects of the treatments on metal availability and soil quality.

\section{Materials and methods}

\section{Site description and experimental set up}

The study site was located on the Acerra plain, Province of Naples, southern Italy (longitude $40^{\circ} 59^{\prime} 56^{\prime \prime} \mathrm{N}$, latitude $14^{\circ} 20^{\prime} 58^{\prime \prime E}$ ), that has volcanic soils particularly suitable for intensive horticultural crops.

The open field trial was carried out on a private farm. This was a specific project and was not part of any agricultural activity due to soil cadmium contamination assessed by environmental monitoring carried out by the Regional Agency for Environmental Protection. Low-quality compost applications such as solid waste burning were recognised to be the main sources of cadmium pollution (ARPAC, 2005). Nevertheless, cadmium concentrations in the soil were low if compared to other polluted sites and, therefore, a medium-term experiment of soil cleanup was considered feasible.

The soil is classified as Vitrandic Haplusepts ashy, glassy, thermic (USDA soil taxonomy), that has developed on ash and pumice deposits and pyroclastic flows that have been redistributed locally by surface water.

Soil texture was sandy-loam according to USDA criteria, with very high carbonate content (average 50\%), sub-alkaline $\mathrm{pH}$, and high organic carbon and nitrogen content (Table 1). Among PTE, Cd was higher than the legal Italian threshold ( 3.1 vs $2.0 \mathrm{mg} \mathrm{kg}^{-1}$ ) for agri-

Table 1. Main chemical and physical soil characteristics.

\begin{tabular}{lccccccccccc}
$\begin{array}{l}\text { Layer } \\
(\mathrm{cm})\end{array}$ & $\begin{array}{c}\mathrm{CaCO}_{3} \\
(\%)\end{array}$ & $\begin{array}{c}\text { Org-N } \\
(\%)\end{array}$ & $\begin{array}{c}\text { Org-C } \\
(\%)\end{array}$ & $\begin{array}{c}\mathrm{SOM} \\
(\%)\end{array}$ & $\begin{array}{c}\mathrm{NO}_{3}-\mathrm{N} \\
(\mathrm{ppm})\end{array}$ & $\begin{array}{c}\mathrm{NH}_{4}-\mathrm{N} \\
(\mathrm{ppm})\end{array}$ & $\mathrm{pH}$ & $\begin{array}{c}\mathrm{EC} \\
\left(\mathrm{pS} \mathrm{cm}{ }^{-1}\right)\end{array}$ & $\begin{array}{c}\text { Particle size distribution (\%) } \\
\text { Sand }\end{array}$ & $\begin{array}{c}\text { Silt } \\
\text { Clay }\end{array}$ \\
$0-20$ & 48.3 & 0.18 & 1.73 & 2.99 & 9.7 & 7.7 & 7.7 & 193.3 & 59.2 & 25.0 & 15.8 \\
$20-40$ & 50.6 & 0.18 & 1.72 & 2.97 & 15.0 & 9.7 & 7.7 & 215.3 & 57.8 & 25.3 & 16.8 \\
\hline $40-60$ & 23.7 & 0.12 & 1.13 & 1.95 & 8.0 & 8.7 & 7.8 & 211.3 & 50.2 & 32.3 & 17.5 \\
\hline
\end{tabular}

$\mathrm{CaCO}_{3}$, calcium carbonate; Org-N, -C, organic nitrogen and carbon; $\mathrm{SOM}$, soil organic matter; $\mathrm{NO}^{3}-\mathrm{N}$, nitric nitrogen ; $\mathrm{NH}_{4}-\mathrm{N}$, ammonia nitrogen; $\mathrm{EC}$, electrical conductivity. 
cultural soils (Table 2).

Compost fertilisation and inoculation of giant reed rhizomes with $T$. harzianum $\mathrm{A6}$ were combined in four different treatments: not inoculated rhizomes and not fertilised (NT-NC); inoculated rhizomes and not fertilised (T-NC); not inoculated rhizomes and compost fertilisation (NT-C); and inoculated rhizomes and compost fertilisation (T-C). Treatments were arranged in a randomised complete block design with three replicates in $132 \mathrm{~m}^{2}(6 \times 22 \mathrm{~m})$ plots.

Compost was a mixture of park, garden and organic fraction of municipal solid wastes, with a content of PTE lower than the threshold values established by the Italian legislation governing fertilisers for green wastes compost (Law 784/94; Legislative Decree 99/92). Compost potential phytotoxicity was excluded (Alluvione et al., 2009) by using Lactuca sativa biomass production in relation to increasing compost doses (Hulzebos et al., 1993). It was manually distributed in fertilised plots on 4/14/2009 at the rate of $20 \mathrm{Mg} \mathrm{ha}^{-1}$, corresponding to $130 \mathrm{~kg} \mathrm{~N}$ $\mathrm{ha}^{-1}$, and then buried with a rotary hoe (4/16/2009). Giant reed rhizomes were transplanted on 4/17/2009 at a depth of $0.20 \mathrm{~m}$ in rows 0.60 $\mathrm{m}$ apart with a density of 2.7 plants $\mathrm{m}^{-2}$. Plants were watered only after transplanting in order to ensure good root contact with the soil, while no irrigation was carried out during the following crop growth period.

In T-NC and T-C plots, rhizomes were first inoculated with $T$. harzianum $\mathrm{A} 6\left(10^{7} \mathrm{CFU} / \mathrm{g}\right)$ by dipping $(24 \mathrm{~h})$ rhizomes in a $100 \mathrm{~mL} / 100$ litre water suspension of a commercial bioregulator [BioplantGuard $®$, Saipan S.r.l., Cava de' Tirreni (SA), Italy]. We decided to use cheap materials (compost, commercial bioregulator) and exclude mineral fertilisation and irrigation in order to assess the effectiveness of a truly low-cost phytoextraction biotechnology.

\section{Plant and soil sampling}

Giant reed was harvested on 11/21/2009 by collecting the plants on 3 rows ( $10 \mathrm{~m}$ long for a total sampling area of $\left.18 \mathrm{~m}^{2}\right)$. A sub-sample (10 plants) was randomly collected to estimate the different yield components (leaves, culms and rhizomes), and then oven dried $\left(65^{\circ} \mathrm{C}\right.$ until constant weight) and shredded for chemical analysis.

Soil samples were a mix of three sub-samples collected at time of transplant and at harvest time at three different points per each plot. Bulk-soil was collected between the rows at 0-20, 20-40 and 40-60 cm layers, while rhizo-soil was obtained by vigorously shaking giant reed roots to separate the loose soil. Soil samples were oven dried $\left(65^{\circ} \mathrm{C}\right.$ until constant weight) and crushed with a mortar for the chemical analysis.

Bulk-soil (from the top layer) and rhizo-soil samples for microbiological analyses were brought to the laboratories and stored in polyethylene bags at $4^{\circ} \mathrm{C}$ for less than $24 \mathrm{~h}$.

\section{Chemical and microbiological analyses}

Soil mineral nitrogen $(\mathrm{N})$ was extracted from $2 \mathrm{~mm}$ sieved samples according to the Hach ${ }^{\circledR}$ method and the extracts were analysed by spectrophotometer at $500\left(\mathrm{NO}_{3}{ }^{-}-\mathrm{N}\right)$ and $425\left(\mathrm{NH}_{4}{ }^{+}-\mathrm{N}\right) \mathrm{nm}$ wavelength (Hach DR2000®, Hach Company, Loveland, CO, USA). Organic N content of soil and plant tissues was measured by the Kjeldahl method.

Total PTE concentration was determined on soil extracts by a Perkin Elmer Analyst $700 \circledR$ atomic absorption spectrometer. The digestion procedure for soil was carried out by using $\mathrm{H}_{2} \mathrm{O}_{2}$ and $\mathrm{HCl}$ : $\mathrm{HNO}_{3}$ solution (3:1) at $250-650 \mathrm{~W}$ for $24 \mathrm{~min}$. The digestion procedure for plants was prepared with an $\mathrm{H}_{2} \mathrm{O}_{2}: \mathrm{HNO}_{3}$ solution (1:3) at 250-600 W for 20 min. The bioavailable fraction of metals was determined with a diethylenetriaminepentaacetic acid (DTPA) extraction solution $0.005 \mathrm{M}$ (0.005 M DTPA, $0.01 \mathrm{M} \mathrm{CaCl} 2$ and 0.10M Triethanolamine adjusted to $\mathrm{pH}$ 7.3). We preferred to use DTPA because in alkaline soils it is more efficient than EDTA (Linsday and Norvell, 1978; Feng et al., 2005).

Extraction vessels were then placed on a reciprocating mechanical shaker for $2 \mathrm{~h}$ at $25^{\circ} \mathrm{C}$ and 60 oscillations per minute and then centrifuged for 5 min at 5000 RPM and immediately filtered with Whatman no. 42. Blank samples were also prepared with the same procedure.

Microbiological analyses were performed according to standard Italian methods. Ten grams of soil samples were shaken in $90 \mathrm{~mL}$ of physiological solution and $0.162 \mathrm{~g}$ of tetrasodium pyrophosphate for 30 min to detach the bacteria from soil particles. After $15 \mathrm{~min}$, to allow soil particles to settle, 10-fold serial dilutions were performed. Selected populations of soil microbial community were detected at $28^{\circ} \mathrm{C}$ in agar and liquid media: i) total aerobic heterotrophic bacteria on Plate Count Agar plates (Oxoid Ltd., Oxford, UK); ii) free-living $\left(\mathrm{N}_{2}\right)$-fixing aerobic bacteria in Augier medium (Augier, 1956); iii) ammonia-oxidising and nitrite-oxidising bacteria in Stanier medium (Stanier et al., 1966).

All tests were carried out in triplicate and microbiological data were expressed as $\log _{10}$ CFU or MPN g ${ }^{-1}$ of DW soil.

\section{Data analyses}

The phytoextraction ability of giant reed was evaluated by calculating two bio-concentration factors:

$\mathrm{BCF}=\mathrm{C}_{\text {roots }} / \mathrm{C}_{\text {soil }}$ and $\mathrm{BCF}=\mathrm{C}_{\text {shoots }} / \mathrm{C}_{\text {soil }}$

where $C$ represents the metal concentration (Mattina et al., 2003).

Moreover, in order to asses the plant ability to translocate PTE from roots to harvestable shoots, a translocation factor was calculated as $\mathrm{TF}=\mathrm{C}_{\text {shoots }} / \mathrm{C}_{\text {shoots+roots }}$ (Ekvall and Greger, 2003).

Statistical analysis was performed by using the MSTAT-C software version 2.0 (Crop and Soil Science Department, Michigan State University, Benton Harbor, MI, USA). A two factor randomised block design was used to assess the effects of compost fertilisation (C) and T. harzianum A6 inoculation (T) on yield, $\mathrm{N}$ and PTEs uptake of giant reed.

A 2-way ANOVA was performed to compare PTE content of different plant organs (rhizomes, culms and leaves) considering compost fertilisation and T. harzianum A6 inoculation as main factors and plant

Table 2. Soil potentially toxic elements content and reference thresholds established by Italian legislation (Legislative Decree 152/06) for agricultural soils.

\begin{tabular}{|c|c|c|c|c|c|}
\hline $\begin{array}{l}\text { Layer } \\
(\mathrm{cm})\end{array}$ & $\begin{array}{c}\mathrm{Zn} \\
\left(\mathrm{mg} \mathrm{kg}^{-1}\right)\end{array}$ & $\begin{array}{c}\mathrm{Cu} \\
\left(\mathrm{mg} \mathrm{kg}^{-1}\right)\end{array}$ & $\begin{array}{c}\mathrm{Cd} \\
\left(\mathrm{mg} \mathrm{kg}^{-1}\right)\end{array}$ & $\begin{array}{c}\mathrm{Pb} \\
\left(\mathrm{mg} \mathrm{kg}^{-1}\right)\end{array}$ & $\begin{array}{c}\mathrm{Cr} \\
\left(\mathrm{mg} \mathrm{kg}^{-1}\right)\end{array}$ \\
\hline $0-20$ & $114.6 \pm 30.5$ & $62.9 \pm 4.9$ & $3.4 \pm 0.3$ & $86.9 \pm 3.8$ & $13.9 \pm 1.4$ \\
\hline $20-40$ & $101.2 \pm 20.8$ & $64.6 \pm 10.3$ & $3.5 \pm 0.1$ & $83.2 \pm 7.5$ & $14.0 \pm 1.4$ \\
\hline $40-60$ & $68.5 \pm 14.9$ & $35.8 \pm 11.8$ & $2.3 \pm 0.2$ & $50.9 \pm 8.3$ & $16.6 \pm 0.6$ \\
\hline Average & $94.7 \pm 28.6$ & $54.4 \pm 16.2$ & $3.1 \pm 0.6$ & $73.7 \pm 18.2$ & $14.8 \pm 1.7$ \\
\hline Threshold & 150.0 & 100.0 & 2.0 & 150.0 & 150.0 \\
\hline
\end{tabular}

Zn, zinc; $\mathrm{Cu}$, copper; $\mathrm{Cd}$, cadmium; $\mathrm{Pb}$, lead; $\mathrm{Cr}$, chromium. 
organs (rhizomes vs stems $v s$ leaves) as sub-factor.

A 2-way ANOVA was also adopted to assess the effect of plant rhizosphere on soil PTE content, considering compost fertilisation and $T$. harzianum A6 inoculation as main factors and soil type (bulk-soil vs rhizo-soil) as sub-factor. The same approach was adopted to assess the effect of treatments and soil type on soil microbial communities. All means were separated by calculating least significant difference at $\mathrm{P}<0.05$.

\section{Results and discussion}

\section{Biomass production and nitrogen uptake}

Total biomass was significantly affected by both $T$. harzianum inoculation and compost fertilisation (Table 3), while aboveground biomass significantly increased only with compost fertilisation. No interaction between the two factors was significant $(\mathrm{P} \leq 0.336)$ for aboveground biomass. Nevertheless, an increase in $3 \mathrm{Mg} \mathrm{ha}^{-1}$ was recorded with T-C compared to the other treatments.

There were no differences in shoot/root ratio among the different treatments (average 6.54) (data not shown), but an increasing trend was found in rhizome biomass production with $\mathrm{T}$ (1.9-2.2 $\mathrm{Mg} \mathrm{ha}^{-1}$, $\mathrm{P}=0.12$ ). Compost fertilisation also positively affected $\mathrm{N}$ content of giant reed tissues (Figure 1A), with a significant increase in culms $(0.5-0.6 \%$ of $\mathrm{N})$, while variations in leaves and total aboveground biomass were close to statistical significance $(\mathrm{P}=0.06$ and 0.08 , respectively). Consequently, aboveground $\mathrm{N}$ uptake (Figure $1 \mathrm{~B}$ ) significantly increased with compost fertilisation, while no variation in $\mathrm{N}$ content of plant tissues and $\mathrm{N}$ uptake occurred with $\mathrm{T}$. harzianum inoculation.

Due to the high resistance of giant reed to soil PTE pollution (Guo and Miao, 2010), the soil cadmium content $\left(3.5 \mathrm{mg} \mathrm{kg}^{-1}\right.$ in the $0-40 \mathrm{~cm}$ layer) did not affect plant growth in our experiment, with an average aboveground production of $13 \mathrm{Mg} \mathrm{ha}^{-1}$ (DW) after eight months of growth.

This value is comparable to those reported by Cosentino et al., 2006 (13.1 $\mathrm{Mg} \mathrm{ha}^{-1}$ ) and Christou, 2001 (13.7 $\mathrm{Mg} \mathrm{ha}^{-1}$ ) in unpolluted soils in Southern Italy and Southern Greece, respectively.

In sandy aerated soils, compost increased $\mathrm{N}$ availability to crops due to the high mineralisation rates (Fagnano et al., 2011; Alluvione et al., 2013) gaining a significant increase in biomass accumulation and $\mathrm{N}$ content. Since our experiment was carried out on a fertile soil $(0.18$ and $1.73 \%$ of $\mathrm{N}$ and $\mathrm{C}$, respectively), we can also suppose there will be an effect of compost as growth regulator due to a hormone-like mechanism (Piccolo et al., 1996; Asli and Neumann, 2010).
T. harzianum is able to enhance plant root activity by mycorrhisation (Windham et al., 1986). In our case, a commercial product used as bioregulator, without any declared specific effect on root activity, was used for rhizome inoculation. We can exclude a positive effect of $T$. harzianum on the $\mathrm{N}$ catching ability of roots, since the $\mathrm{N}$ content of plant tissues was not affected by the treatment. Besides, the increase in total biomass can be interpreted as a root growth induction, since $T$. harzianum inoculation did not affect aboveground biomass.

The higher values of aboveground biomass recorded with T-C, could be due to the ability of T. harzianum inoculated rhizomes to catch mineral $\mathrm{N}$ from compost degradation; this trend will probably be confirmed in the next few years of the trial.

\section{Potentially toxic elements uptake and translocation by plants}

A 2-way ANOVA on PTE content of plant tissues was made by fixing compost fertilisation and T. harzianum A6 inoculation as main factors and plant organs as sub-factor. A significant effect of plant organs was found for all the average values of metals traced (Figure 2), while the highest interaction was significant only for Cd (Figure 3).

Leaves showed the highest $\mathrm{Cu}$ and $\mathrm{Cd}$ content (12.4 and $5.1 \mathrm{mg} \mathrm{kg}^{-1}$, respectively), $\mathrm{Zn}$ levels were found to be the same in rhizome and leaves (average $14.5 \mathrm{mg} \mathrm{kg}^{-1}$ ) while culms were the main sink for $\mathrm{Cr}$ (12.5 mg kg-1). Chromium preferential allocation in culms may be due to $\mathrm{Cr}$ (III) adsorption on lignin through the ion-exchange mechanism and formation inner-sphere complexes (Wu et al., 2008). In comparison to control plots (NT-NC), Cd content of rhizome showed increases of

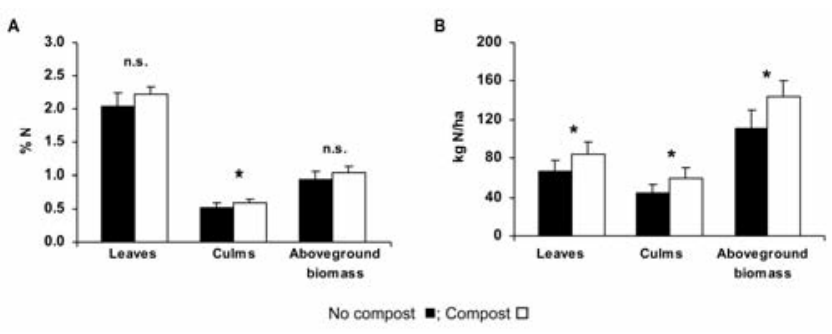

Figure 1. Effect of compost fertilisation: A) nitrogen (N) content; B) $\mathrm{N}$ uptake in giant reed leaves, culms and aboveground biomass (mean values and standard deviations). n.s., not significant; ${ }^{*} \mathbf{P} \leq \mathbf{0 . 0 5}$.

Table 3. Average effect of inoculation and compost fertilisation: productive behaviour of giant reed.

\begin{tabular}{|c|c|c|c|c|c|}
\hline Factors & $\begin{array}{l}\text { Total biomass } \\
\text { (Mg ha-1 DW) }\end{array}$ & $\begin{array}{l}\text { Aboveground biomass } \\
\text { (Mg ha-1 DW) }\end{array}$ & $\begin{array}{c}\text { Leaves } \\
\left(\mathrm{Mg} \mathrm{ha}^{-1} \mathrm{DW}\right)\end{array}$ & 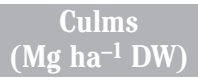 & $\begin{array}{c}\text { Rhizomes } \\
\left(\mathrm{Mg} \mathrm{ha}^{-1} \mathrm{DW}\right)\end{array}$ \\
\hline \multicolumn{6}{|l|}{ Inoculation } \\
\hline NT & $13.9 \pm 1.9$ & $12.0 \pm 1.6$ & $3.3 \pm 0.8$ & $8.7 \pm 1.2$ & $1.9 \pm 0.4$ \\
\hline $\mathrm{T}$ & $15.8 \pm 1.8$ & $13.6 \pm 2.0$ & $3.8 \pm 0.7$ & $9.9 \pm 1.2$ & $2.2 \pm 0.4$ \\
\hline \multicolumn{6}{|l|}{ Fertilisation } \\
\hline $\mathrm{NC}$ & $13.9 \pm 2.2$ & $11.8 \pm 1.9$ & $3.2 \pm 0.7$ & $8.6 \pm 1.3$ & $2.1 \pm 0.5$ \\
\hline C & $15.8 \pm 1.7$ & $13.8 \pm 1.6$ & $3.8 \pm 0.7$ & $10.0 \pm 1.4$ & $2.0 \pm 0.3$ \\
\hline \multicolumn{6}{|l|}{ Significance $^{\circ}$} \\
\hline Inoculation & $*$ & n.s. & n.s. & n.s. & n.s. \\
\hline Fertilisation & $*$ & $*$ & n.s. & n.s. & n.s. \\
\hline Inoculation $\mathrm{x}$ fertilisation & n.s. & n.s. & n.s. & n.s. & n.s. \\
\hline
\end{tabular}

\footnotetext{
$\mathrm{NT}$, no trichoderma; $\mathrm{T}$, trichoderma; $\mathrm{NC}$, no compost; $\mathrm{C}$, compost; n.s., not significant. ${ }^{*} \mathrm{P} \leq 0.05$; ${ }^{\circ}$ Level of significance of inoculation, compost fertilisation and of the interaction inoculation $\mathrm{x}$ fertilisation.
} 
$48 \%, 35 \%$ and $48 \%$ with T-NC, NT-C and T-C, respectively. Moreover, T$\mathrm{C}$ allowed also an increase in $\mathrm{Cd}$ content in leaves $(+22 \%)$. Cd total and aboveground uptake was positively affected by both main factors on the average (Table 4). The $30 \%$ increase due to compost fertilisation was mainly related to uptake of leaves and culms. On the contrary, the effect of T. harzianum A6 (+18\% of total Cd uptake) may be due to an increase in rhizome uptake. From the interaction between compost and T. harzianum (Figure 4), it is also possible to see that all the different treatments allowed an increase of approximately $60 \%$ of $\mathrm{Cd}$ uptake by rhizome. Treatments also led to a $17 \%$ increase in $\mathrm{Cu}$ and $\mathrm{Cr}$ uptakes, both total and aboveground (data not shown) but values were below the 0.05 threshold ( $\mathrm{P}=0.06$ and 0.10 , respectively).

The positive effect of compost fertilisation can be traced back to the high chelating ability of humic acids derived from compost degradation during the crop cycle. Furthermore, the soil used in our experiment could have emphasised this effect because acidification due to microbial activity increases metal bioavailability in alkaline soil (Santibáñez et al., 2008; Fornes et al., 2009; Fagnano et al., 2011). As regards the T. harzianum $\mathrm{A6}$ effect, both an active uptake by the fungus and an increase in root $\mathrm{Cd}$ availability could have contributed to the increase in the rhizome $\mathrm{Cd}$ content. The highest $\mathrm{Cd}$ content in leaves with T-C could be explained by the combined effect of the increased metal bioavailability and the improved uptake ability that raised the $\mathrm{Cd}$ con-

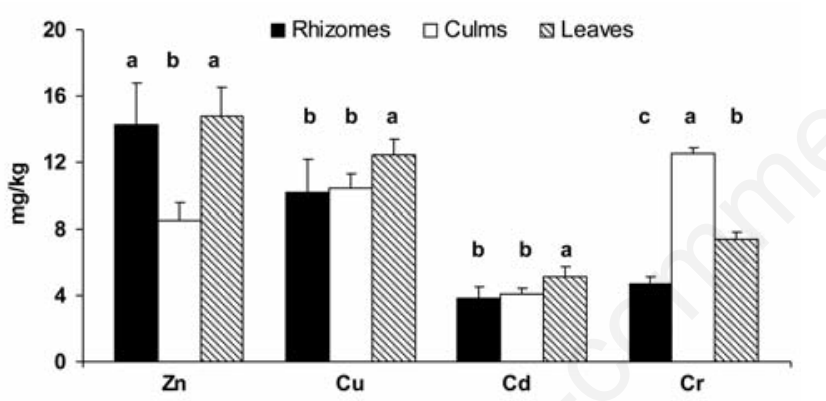

Figure 2. Average potentially toxic elements (PTE) content in giant reed tissues (mean values and standard deviations). $\mathrm{Zn}$, zinc; $\mathrm{Cu}$, copper; $\mathrm{Cd}$, cadmium; $\mathrm{Cr}$, chromium. Values with the same letter were not significantly different $(P \leq 0.05)$ for each PTE.

Table 4. Average effect of inoculation and compost fertilisation: cadmium uptake of giant reed.

\begin{tabular}{|c|c|c|c|c|c|}
\hline Factors & $\begin{array}{c}\text { Total } \\
\left(\mathrm{g} \mathrm{ha}^{-1}\right)\end{array}$ & $\begin{array}{l}\text { Aboveground } \\
\left(\mathrm{g} \mathrm{ha}^{-1}\right)\end{array}$ & $\begin{array}{l}\text { Leaves } \\
\left(\mathrm{g} \mathrm{ha}^{-1}\right)\end{array}$ & $\begin{array}{l}\text { Culms } \\
\left(\mathrm{g} \mathrm{ha}^{-1}\right)\end{array}$ & $\begin{array}{l}\text { Rhizomes } \\
\left(\mathrm{g} \mathrm{ha}^{-1}\right)\end{array}$ \\
\hline \multicolumn{6}{|l|}{ Inoculation } \\
\hline NT & $58.8 \pm 9.6$ & $52.0 \pm 8.1$ & $35.5 \pm 4.4$ & $16.4 \pm 5.3$ & $6.9 \pm 2.4$ \\
\hline $\mathrm{T}$ & $69.8 \pm 14.0$ & $61.1 \pm 13.4$ & $40.9 \pm 5.6$ & $20.3 \pm 9.0$ & $8.7 \pm 1.7$ \\
\hline \multicolumn{6}{|l|}{ Fertilisation } \\
\hline $\mathrm{NC}$ & $56.0 \pm 10.1$ & $48.9 \pm 8.3$ & $33.3 \pm 3.9$ & $15.6 \pm 5.1$ & $7.1 \pm 3.9$ \\
\hline $\mathrm{C}$ & $72.7 \pm 9.7$ & $64.2 \pm 9.3$ & $43.1 \pm 5.2$ & $21.1 \pm 6.4$ & $8.5 \pm 5.2$ \\
\hline \multicolumn{6}{|l|}{ Significance $^{\circ}$} \\
\hline Inoculation & $*$ & $*$ & n.s. & n.s. & * \\
\hline Fertilisation & $* *$ & $* *$ & $*$ & $* *$ & n.s. \\
\hline Inoculation x fertilisation & n.s. & n.s. & n.s. & n.s. & $*$ \\
\hline
\end{tabular}

tent of rhizome up to the point of saturation, thus enhancing the sink effect of the leaves.

The results obtained in this field trial allow us to estimate the total reclamation time, defined as the time required to clean up a soil by phytoextraction, given the soil conditions of this experiment. The soil $\mathrm{Cd}$ content at the start of the experiment was $3.45 \mathrm{mg} \mathrm{kg}^{-1}(0-40 \mathrm{~cm}$ layer$)$, and according to a bulk density of $1.20 \mathrm{Mg} \mathrm{m}^{-3}$, a total removal of 6960 $\mathrm{g} \mathrm{ha}^{-1}$ is required for $\mathrm{Cd}$ content to be under the legal threshold ( $2 \mathrm{mg}$ $\mathrm{kg}^{-1}$; Legislative Decree 152/06). Therefore, considering the aboveground biomass yield and the average plant $\mathrm{Cd}$ uptake obtained with compost fertilisation, this would take 106 years (6960 $\mathrm{g} \mathrm{ha}^{-1} / 64 \mathrm{~g} \mathrm{ha}^{-1}$ year $^{-1}$ ). The total reclamation time may be reduced 4 -fold if an average biomass production of $40 \mathrm{Mg} \mathrm{ha}^{-1} \mathrm{DW}$ was considered. This yield level is commonly obtained with giant reed in Italy from the $2^{\text {nd }}-3^{\text {rd }}$ cropping year (Angelini et al., 2005, 2009; Cosentino et al., 2006) and it could be easily obtained also on our site due to the low Cd pollution level and high soil fertility. Obviously, there could be a significant reduction in reclamation time if total uptake is taken into account, considering that at the end of the reclamation period all the rhizomes also have to be removed from the soil. Nevertheless, we decided not to take this into consideration because we do not know enough about the growth and metal accumulation of giant reed rhizomes and this could result in unrealistic estimations being made.

Figure 3. Effect of trichoderma inoculation $x$ compost fertilisation $x$ plant organ interaction on cadmium content in giant reed (mean values and standard deviations). NT, no trichoderma; NC, no compost; $C$, compost; $T$, trichoderma. Values with the same letter were not significantly different $(P \leq 0.05)$.

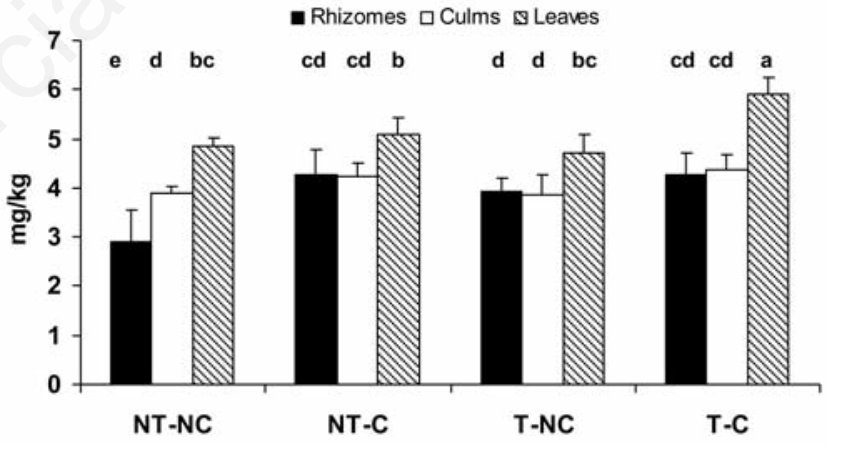




\section{Bioconcentration and translocation factors}

Cadmium bioconcentration and translocation factors (BCF, BCF' and TF) were on average higher than 1 (Table 5) while the values were very low for the other PTE analysed (data not shown). Cd BCF was an average 1.2 , and was $231 \%$ of that calculable from data reported by Guo and Miao (2010) on a soil with low Cd content (1.1 mg kg-1). In our case, the soil Cd content was three times higher, but the ability of giant reed to concentrate $\mathrm{Cd}$ could have been emphasised by the high soil fertility and by the absence of limited concentrations of the other PTE.

There was a significant increase in bioconcentration with compost fertilisation $(+15 \%$ and $+25 \%$ for BCF and BCF', respectively), thus indicating that no problems occurred in giant reed uptake when $\mathrm{Cd}$ bioavailability increased.

\section{Soil potentially toxic elements content}

As expected, PTE soil content was not affected by the treatments and there was no significant difference in $\mathrm{Cu}$ and $\mathrm{Cd}$ contents of bulk soil in top layer $(0-20 \mathrm{~cm})$ and those measured at time of transplant (Tables 2 and 6). Focusing on PTE content of rhizo-soil, a significant increase in trace metal concentration was found (Table 6) if compared to the bulk-soil, with the exception of $\mathrm{Cr}$. The rhizosphere activity (chelating biological agents from root exudates and microbial metabolism) and the mass flows of soil solution due to root suction may be identified as the main causes of this increase. The different behaviour of $\mathrm{Cr}$ may be due to its lower mobility since it is strongly retained by soil particles (Stewart et al., 2003; Fendorf, 1995).

Since the DTPA extraction was made on soil samples collected at the end of growth cycle, it could represent the residual content of bioavailable metals resulting from the combined action of the treatments and of plant uptake.

The percentages of bioavailable $\mathrm{Cd}, \mathrm{Zn}$ and $\mathrm{Cu}$, compared with total content, were $9 \%, 9 \%$ and $47 \%$ in bulk-soil and $10 \%, 7 \%$ and $39 \%$ in rhizo-soil, respectively (Tables 6 and 7). Bioavailable $\mathrm{Cd}$ was higher in rhizo-soil than in bulk-soil. This could be because it tends to form outer-sphere complex on soil colloid surfaces and thus is more mobile

Table 5. Average effect of inoculation and compost fertilisation: bioconcentration and translocation factors for cadmium.

\begin{tabular}{|c|c|c|c|}
\hline Factors & $\mathrm{BCF}$ & BCF" & $\mathrm{TF}$ \\
\hline $\begin{array}{l}\text { Inoculation } \\
\text { NT } \\
\mathrm{T}\end{array}$ & $\begin{array}{l}1.00 \pm 0.08 \\
1.14 \pm 0.08\end{array}$ & $\begin{array}{l}1.23 \pm 0.15 \\
1.22 \pm 0.11\end{array}$ & $\begin{array}{l}1.30 \pm 0.13 \\
1.07 \pm 0.38\end{array}$ \\
\hline $\begin{array}{l}\text { Fertilization } \\
\text { NC } \\
\text { C }\end{array}$ & $\begin{array}{l}0.95 \pm 0.05 \\
1.19 \pm 0.08\end{array}$ & $\begin{array}{l}1.14 \pm 0.08 \\
1.32 \pm 0.12\end{array}$ & $\begin{array}{l}1.26 \pm 0.14 \\
1.11 \pm 0.39\end{array}$ \\
\hline $\begin{array}{l}\text { Significance }^{\circ} \\
\text { Inoculation } \\
\text { Fertilisation } \\
\text { Inoculation x fertilisation }\end{array}$ & $\begin{array}{c}\text { n.s. } \\
* \\
\text { n.s. }\end{array}$ & $\begin{array}{c}\text { n.s. } \\
* \\
\text { n.s. }\end{array}$ & $\begin{array}{l}\text { n.s. } \\
\text { n.s. } \\
\text { n.s. }\end{array}$ \\
\hline
\end{tabular}

BCF, bioconcentration factor (roots/soil ratio); BCF', bioconcentration factor (shoots/soil ratio); TF, translocation factor (shoots/shoots+roots ratio); NT, no trichoderma; T, trichoderma; NC, no compost; C, compost; n.s., not significant. ${ }^{*} \mathrm{P} \leq 0.05$; ${ }^{\circ}$ Level of significance of inoculation, compost fertilisation and of the interaction inoculation $\mathrm{x}$ fertilisation.

Table 6. Average potentially toxic elements content in bulk-soil $(0-20 \mathrm{~cm}$ layer $)$ and rhizo-soil.

\begin{tabular}{|c|c|c|c|c|}
\hline Treatments & $\begin{array}{c}\mathrm{Zn} \\
\left(\mathrm{mg} \mathrm{kg} \mathrm{g}^{-1}\right)\end{array}$ & $\begin{array}{c}\mathrm{Cu} \\
\left(\mathrm{mg} \mathrm{kg} \mathrm{g}^{-1}\right)\end{array}$ & $\begin{array}{c}\text { Cd } \\
\left.(\mathrm{mg} \mathrm{kg})^{-1}\right)\end{array}$ & $\begin{array}{c}\mathrm{Cr} \\
(\mathrm{mg} \mathrm{kg-1})\end{array}$ \\
\hline Bulk-soil & $93.7 \pm 12.5$ & $66.6 \pm 8.0$ & $3.7 \pm 0.25$ & $15.2 \pm 2.0$ \\
\hline Rhizo-soil & $115.9 \pm 20.3$ & $74.9 \pm 8.0$ & $3.9 \pm 0.16$ & $13.9 \pm 1.7$ \\
\hline Significance $^{\circ}$ & $*$ & $* *$ & $* *$ & $*$ \\
\hline
\end{tabular}

$\mathrm{Zn}$, zinc; $\mathrm{Cu}$, copper; $\mathrm{Cd}$, cadmium; $\mathrm{Cr}$, chromium. ${ }^{*} \mathrm{P} \leq 0.05,{ }^{*} \mathrm{P} \leq 0.01$; ${ }^{\circ}$ Level of significance.

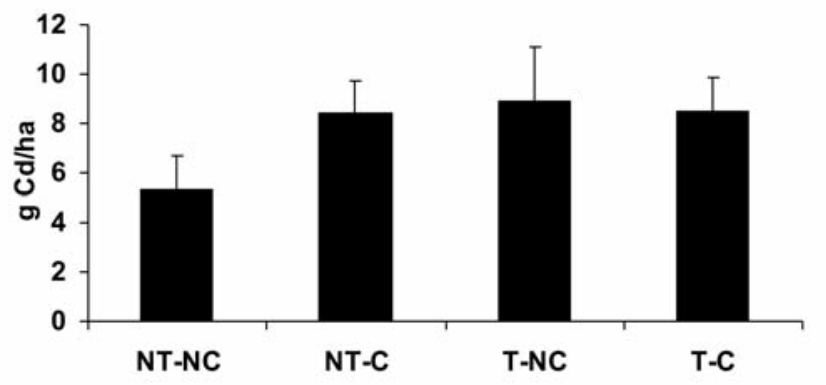

Figure 4. Effect of inoculation $\mathrm{x}$ compost fertilisation interaction on cadmium $(\mathrm{Cd})$ uptake by rhizomes (mean values and standard deviations). NT, no trichoderma; NC, no compost; C, compost; T, trichoderma.
Table 7. Diethylenetriaminepentaacetic acid extracted cadmium, zinc and copper from bulk-soil and rhizo-soil of Arundo donax.

\begin{tabular}{lccc} 
& \multicolumn{1}{c}{ Cd } & $\begin{array}{c}\mathrm{Znn} \\
\left(\mathrm{mg} \mathrm{kg}^{-1}\right)\end{array}$ & $\mathrm{Cu}$ \\
Bulk-soil & $0.33 \pm 0.02$ & $8.55 \pm 1.11$ & $31.48 \pm 3.2$ \\
Rhizo-soil & $0.39 \pm 0.03$ & $8.35 \pm 1.33$ & $29.54 \pm 3.1$ \\
\hline Significance & $\mathrm{P} \leq 0.01$ & n.s. & 0.090 \\
\hline
\end{tabular}

Cd, cadmium; Zn, zinc; Cu, copper; n.s., not significant. 
than the other metals (Alloway, 1995).

Bioavailable $\mathrm{Cd}$ and $\mathrm{Zn}$ contents were lower than those reported by other researchers (Meers et al., 2007; Shaheen et al., 2009; Yang et al., 2011) because the high content of carbonate of the soil used in this experiment (59\% in a $0-20 \mathrm{~cm}$ layer) could have reduced metal mobility adsorbing them on carbonate surface. A negative correlation between $\mathrm{Cd}$ mobility and soil $\mathrm{CaCO}_{3}$ content was also reported by Shaheen et al. (2009).

The effects of treatments were significant only in bulk-soil where compost increased bioavailable $\mathrm{Cd}(+9 \%)$ and Trichoderma reduced bioavailable $\mathrm{Cu}(-7.4 \%)$ (Table 8$)$.

The difference in metal content between bulk-soil and rhizo-soil can be related to the effects of plants on metal mobility. Since they are micronutrients, $\mathrm{Zn}$ and $\mathrm{Cu}$ are lower in rhizosphere as a consequence of the plant uptake, while $\mathrm{Cd}$ increases in rhizo-soil likely because root exudates could increase its mobility. Meanwhile, plant uptake is lower because it is not an essential element for plant nutrition (Cieśliński et al., 1998).

The effect of compost on Cd bioavailability could be related to chelating/complexing reactions by acid functional groups of humic sub- stances that can reduce the precipitation as hydroxid/carbonate expected in an alkaline and carbonatic soil (Clemente and Bernal, 2006; Bianchi et al., 2008). These results confirm the findings of an experiment carried out in a similar environment (Fagnano et al., 2011).

\section{Soil microbial dynamics}

Microbial parameters were used to evaluate the influence of plant growth and agronomic treatments on the growth of microflora related to the $\mathrm{N}$ cycle. According to the 2-Way ANOVA, all the microbial populations analysed were highly affected by both compost addiction, $T$. harzianum A6 inoculation and soil type (rhizo and bulk), and a significant compost $\mathrm{x}$ soil type interaction was also found (data not shown). The highest interaction (compost fertilisation x T. harzianum inoculation x soil type) was significant for total aerobic heterotrophic bacteria, free-living $\left(\mathrm{N}_{2}\right)$-fixing bacteria and nitrite-oxidizers (Figure 5).

The number of total aerobic heterotrophic bacteria (Figure 5A) was always higher in rhizo-soil than in bulk-soil (10\% increase) and this increased with compost fertilisation, particularly emphasised in bulksoil. These results may be related to the high $\mathrm{C}$ and $\mathrm{N}$ availability derived from plant exudation in rhizo-soil (Sørensen and Sessitsch,
A

\section{Total Aerobic Heterotrophic Bacteria}

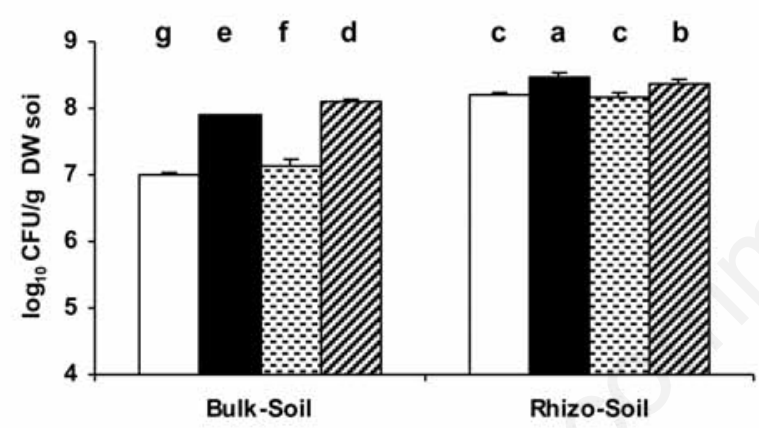

C

Ammonia oxidizing bacteria

n.s

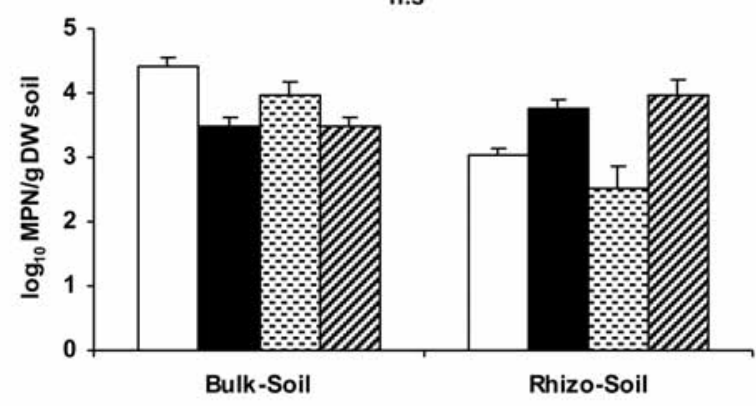

$\square \mathrm{NT}-\mathrm{NC}$

- NT-C

B

\section{$\mathrm{N}_{2}$-fixing free-living bacteria}

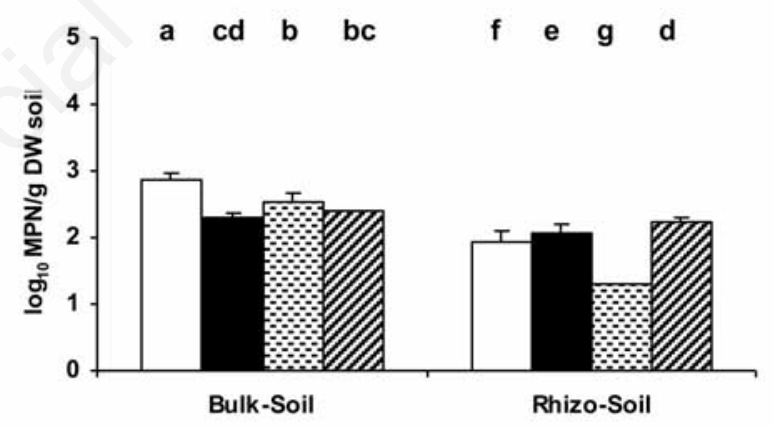

D

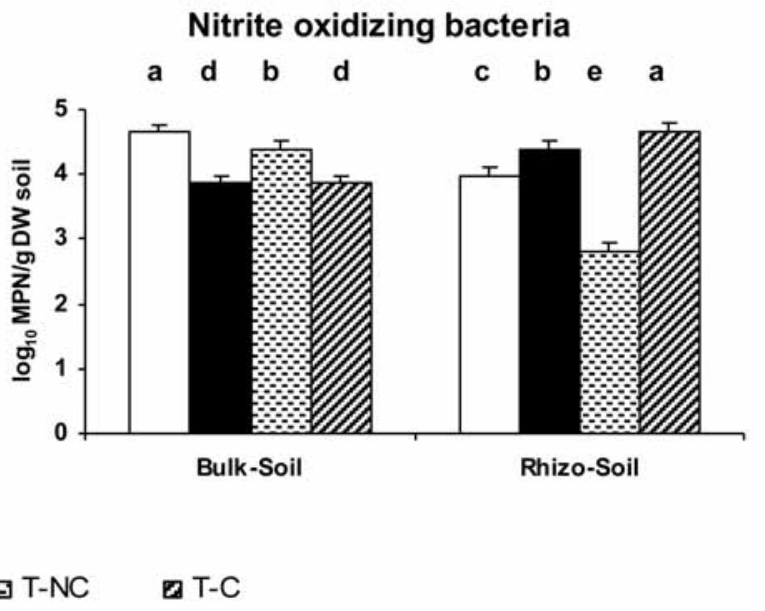

Figure 5. Effect of inoculation $x$ compost fertilisation $x$ soil type interaction on total aerobic heterotrophic bacteria (A), N2-fixing freeliving bacteria (B), ammonia-oxidizing bacteria (C) and nitrite-oxidizing bacteria (D) (mean values and standard deviations). NT, no trichoderma; NC, no compost; C, compost; T, trichoderma; n.s., not significant. Values with the same letter were not significantly different $(P \leq 0.05)$. 
Table 8. Effect of compost and trichoderma on diethylenetriaminepentaacetic acid extracted cadmium, zinc and copper.

\begin{tabular}{|c|c|c|c|c|c|c|}
\hline & $\mathrm{Cd}$ & $\begin{array}{l}\text { Bullk-soil } \\
\text { Zn } \\
\left(\mathrm{mg} \mathrm{kg}^{-1}\right)\end{array}$ & $\mathrm{Cu}$ & Cd & $\begin{array}{l}\text { Rhizo-soil } \\
\text { Zn } \\
\left(\mathrm{mg} \mathrm{kg}^{-1}\right)\end{array}$ & $\mathrm{Cu}$ \\
\hline \multicolumn{7}{|l|}{ Treatment } \\
\hline NT & $0.33 \pm 0.02$ & $8.55 \pm 1.02$ & $32.68 \pm 2.95$ & $0.39 \pm 0.04$ & $8.41 \pm 1.19$ & $29.59 \pm 2.77$ \\
\hline $\mathrm{T}$ & $0.33 \pm 0.02$ & $8.55 \pm 1.29$ & $30.27 \pm 3.23$ & $0.40 \pm 0.03$ & $8.28 \pm 1.57$ & $29.48 \pm 3.59$ \\
\hline Significance & n.s. & n.s. & $*$ & n.s. & n.s. & n.s. \\
\hline \multicolumn{7}{|l|}{ Treatment } \\
\hline NC & $0.32 \pm 0.02$ & $8.59 \pm 1.18$ & $31.88 \pm 4.00$ & $0.38 \pm 0.04$ & $8.24 \pm 1.25$ & $29.23 \pm 3.48$ \\
\hline $\mathrm{C}$ & $0.34 \pm 0.01$ & $8.51 \pm 1.15$ & $31.07 \pm 2.50$ & $0.41 \pm 0.02$ & $8.45 \pm 1.51$ & $29.84 \pm 2.87$ \\
\hline Significance & $* *$ & n.s. & n.s. & 0.14 & n.s. & n.s. \\
\hline
\end{tabular}

Cd, cadmium; Zn, zinc; Cu, copper; NT, no trichoderma; T, trichoderma; NC, no compost; C, compost; n.s., not significant; ${ }^{*} \mathrm{P}<0.05$; ${ }^{* *} \mathrm{P} \leq 0.01$

2007) and to the mineralisation of organic matter contained in compost (Branzini et al., 2009). Moreover, it has been reported that the number of fast-growing heterotrophic bacteria is not affected by the presence of PTE because metal exposure leads to the establishment of a tolerant microbial population that is able to use the nutrients available in this type of environment (Kelly et al., 2003; Piotrowska-Seget et al., 2005; Garau et al., 2007; Castaldi et al., 2009). In fact, total aerobic heterotrophic bacteria comprise sensitive and tolerant populations that may alter heavy metal availability in their vicinity by producing compounds which complex metal or by acidifying their environment (Giller et al., 1998).

The effect of treatments on PTE availability was highlighted by $\mathrm{N}$ cycling bacteria that followed a different pattern to that of total aerobic heterotrophic bacteria (Figure 5B-D). An inhibitory effect of rhizosphere on nitrite oxidizing bacteria (Figure 5D) is clearly shown in control plots (NT-NC) by the reduction of 14\% (rhizo-soil $v$ s bulk-soil), while compost fertilisation and rhizome inoculation affected microbial growth differently in the two soil types.

As compared to control plots (NT-NC), a 17\% reduction was found with NT-C and T-C in bulk-soil while the same treatments increased microbial population in rhizo-soil (average $+13 \%$ ). Moreover, in the rhizo-soil as compared to bulk-soil, a strong reduction in nitrite-oxidising bacteria with T-NC (-36\%) and a significant increase with compost addition ( $+14 \%$ and $+20 \%$ for NT-C and T-C, respectively) were found. Free-living $\left(\mathrm{N}_{2}\right)$-fixing bacteria and ammonia-oxidising bacteria (Figure 5B and C) showed a similar pattern but a stronger difference among population number in bulk and rhizo-soil was found ( $23 \%$ and $13 \%$ decrease, respectively).

The ammonia and nitrite-oxidising bacteria are particularly sensitive to heavy metal content of soil solution (Chandran and Love, 2008), but the negative effect on nitrification of ammonium and/or nitrite ions is also well known. Since no differences in soil mineral $\mathrm{N}$ content occurred after compost fertilisation (data not shown), the reduction in nitrite-oxidising bacteria in bulk-soil (NT-C and T-C vs. NT-NC) could easily be interpreted as a result of the increased metal availability proved by giant reed uptakes (see above). On the contrary, compost fertilisation was able to increase the nitrite-oxidising community in rhizo-soil, probably because the high uptake ability of giant reed reduced the availability of metals to microbes allowing an increase in their biomass as a side effect of organic fertilisation. The negative effect of plant activity on nitrite-oxidising bacteria, revealed by the decrease in population in control plots (rhizo-soil vs bulk-soil) was probably caused both by increased metal availability due to metal chelating compounds, and by plant competition for mineral N (Herman et al., 2006; Glaser et al., 2010).

The big reduction in nitrite-oxidising bacteria found with T-NC versus control plots is in agreement with the increased root activity of inoculated rhizomes. Moreover, this effect could also be due to high soil colonisation, production of toxic metabolites, and competition for nutrients. Interestingly, the T. harzianum A6 effect was still evident even eight months after inoculation, while usually this only lasts two months (Harman et al., 2004).

\section{Conclusions}

The results of this field experiment highlighted the high productive potentiality of giant reed on a low polluted soil, showing a profitable way to use soils not suitable for food production. The estimated reclamation may be reduced to approximately 25 years but this could still be too long to meet the requirements of environmental decision makers. Nevertheless, any cost-benefit evaluation should also take into account the low cost of this phytoremediation technique and the potential profits from bio-energy and biopolymer production.

The preferential allocation of $\mathrm{Cr}$ in culms could create some problems for the energy conversion of giant reed biomasses. In fact, due to the a-specific hypertolerance of giant reed to mineral pollutants, there could be a significant increase in $\mathrm{Cr}$ concentration in culms grown on highly polluted soils. Therefore, metal toxicity may seriously limit the microbial driven conversion of lignin-cellulose to second generation ethanol or biopolymers. In these conditions, only combustion or pyrogasification in a power plant, followed by ash decontamination through hydrometallurgical processes seems advisable.

Compost fertilisation was shown to be a useful tool to increase both PTE and mineral N availability to crops while Trichoderma harzianum A6 inoculation was able to increase only PTE uptake. Further efforts are needed to improve assisted phytoremediation with mycorrhizal fungi by selecting strains with higher capacity to uptake specific mineral pollutants. Moreover, bacteria involved in nitrogen cycle were seen to be useful biomonitors to assess soil quality and PTE bioavailability, representing a viable complementary technique to the common soil chemical analyses. Over the following years, further research has been planned to assess the residual effects of the treatments on PTE bioavailability and on the phytoremediation efficiency in the long term, particularly when giant reed gains the maximum yield levels. 


\section{References}

Adams P, De-Leij F, Lynch JM, 2007. Trichoderma harzianum Rifai 129522 mediates growth promotion of crack willow (Salix fragilis) saplings in both clean and metal-contaminated soil. Microb. Ecol. 54:306-13.

Alloway BJ, 1995. Soil processes and the behaviour of heavy metals. In: B.J. Alloway (ed.) Heavy metals in soils. Chapman \& Hill, London, UK, pp 11-37.

Alluvione F, Fiorentino N, Bertora C, Zavattaro L, Fagnano M, Quaglietta Chiarandà F, Grignani C, 2013. Short-term crop and soil response to $\mathrm{C}$-friendly strategies in two contrasting environments. Eur. J. Agron. 45:114-23.

Alluvione F, Fiorentino N, Fagnano M, Bertora C, Zavattaro L, Grignani C, 2009. Corn management: can compost help to substitute mineral fertilizers? pp 353-358 in Proc. Ecomondo Conference, October 28th-31th 2009, Maggioli Ed., Rimini, Italy.

Alorro RD, Mitani S, Hiroyoshi N, Ito M, Tsunekawa M, 2008. Recovery of heavy metals from MSW molten fly ash by carrier-in-pulp method: Fe powder as carrier. Minerals Eng. 21:1094-101.

Alvarenga P, Gonçalves AP, Fernandes RM, de Varennes A, Vallini G, Duarte E, Cunha-Queda AC, 2009. Organic residues as immobilizing agents in aided phytostabilization: (I) effects on soil chemical characteristics. Chemosphere 74:1292-300.

Angelini LG, Ceccarini L, Bonari E, 2005. Biomass yield and energy balance of Giant reed (Arundo donax L.) cropped in central Italy as related to different management practices. Eur. J. Agron. 22:375-89.

Angelini LG, Ceccarini L, Nassi o Di Nasso N, Bonari E, 2009. Comparison of Arundo donax L. and Miscanthus $\mathrm{x}$ giganteus in a long-term field experiment in Central Italy: Analysis of productive characteristics and energy balance. Biomass Bioener. 33:635-43.

ARPAC, 2005. Piano Regionale di bonifica dei siti inquinati della regione Campania. Available from: http://www.sito.regione. campania.it/ burc/pdf05/burcsp09_09_05/pianoregionale_bonifica.pdf

Asli S, Neumann PM, 2010. Rhizosphere humic acid interacts with root cell walls to reduce hydraulic conductivity and plant development. Plant Soil 336:313-22.

Augier J, 1956. A propos de la numération des azotobacter en milieu liquide. Ann. Inst. Pasteur 91:760-5.

Bianchi V, Masciandaro G, Giraldi D, Ceccanti B, Iannelli R, 2008. Enhanced heavy metal phytoextraction from marine dredged sediments comparing conventional chelating agents (citric acid and EDTA) with humic substances. Water Air Soil Pollut. 193:323-33.

Black H, 1999. Phytoremediation: a growing field with some concerns. Scientist 13:1.

Branzini A, Zubillaga MS, Zubillaga MM, 2009. Microbial response to application of amendments in a contaminated soil with trace elements. Am. J. Environ. Sci. 5:94-8.

Broos K, Mertens J, Smolders E, 2005. Toxicity of heavy metals in soil assessed with various soil microbial and plant growth assays: a comparative study. Environ. Toxicol. Chem. 24:634-40.

Cao LX, Jiang M, Zeng ZR, Du AX, Tan HM, Liu YH, 2008. Trichoderma atroviride F6 improves phytoextraction efficiency of mustard (Brassica juncea (L.) Coss. var. foliosa Bailey) in Cd, Ni contaminated soils. Chemosphere 71:1769-73.

Castaldi P, Melis P, Solvetti M, Deiana P, Garau G, 2009. Influence of pea and wheat growth on $\mathrm{Pb}, \mathrm{Cd}$, and $\mathrm{Zn}$ mobility and soil biological status in a polluted amended soil. Geoderma 151:241-8.

Cela S, Sumner ME, 2002. Critical concentrations of copper, nickel, lead, and cadmium in soils based on nitrification. Commun. Soil Sci. Plant Anal. 33:19-30.

Chandran K, Love NG, 2008. Physiological state, growth mode, and oxida- tive stress play a role in Cd(II)-mediated inhibition of Nitrosomonas europaea 19718. Appl. Environ. Microbiol. 74:2447-53.

Chaney RL, Li YM, Brown SL, Homer FA, Malik M, Angle JS, Baker AJM, Reeves RD, Chin M, 2000. Improving metal hyperaccumulator wild plants to develop commercial phytoextraction systems: approaches and progress. In: N. Terry, G. Bañuelos (eds.) Phytoremediation of contaminated soil and water. Lewis Publications, Boca Raton, FL, USA, pp 129-158.

Chary NS, Kamala CT, Raj DSS, 2008. Assessing risk of heavy metals from consuming food grown on sewage irrigated soils and food chain transfer. Ecotoxicol. Environ. Saf. 69:513-24.

Chen G, Andries J, Spliethoff H, Fang M, Van de Enden PJ, 2004. Biomass gasification integrated with pyrolysis in a circulating fluidised bed. Solar Ener. 76:345-9.

Christou M, 2001. Giant reed in Europe. In: S. Kyritsis, A.A.C.M. Beenackers, P. Helm, A. Grassi, D. Chiaramonti (eds.) Biomass for energy and industry. Proc. 1st World Conference, 5-9 June, Sevilla, Spain. James and James, Science Publishers Ltd, London, UK, pp 2089-2091.

Cieśliński G, van Rees KCJ, Szmigielska AM, Krishnamurti GST, Huang PM, 1998. Low-molecular-weight organic acids in rhizosphere soils of durum barley and their effect on cadmium bioaccumulation. Plant Soil 203:109-17.

Clemente R, Bernal MP, 2006. Fractionation of heavy metals and distribution of organic carbon in two contaminated soils amended with humic acids. Chemosphere 64:1264-73.

Conte P, Agretto A, Spaccini R, Piccolo A, 2005. Soil remediation: humic acids as natural surfactants in the washings of highly contaminated soils. Environ. Pollut. 135:515-22.

Cosentino SL, Copani V, D’Agosta GM, Sanzone E, Mantineo M, 2006. First results on evaluation of Arundo donax L. clones collected in Southern Italy. Industr. Crops Prod. 23:212-22.

do Nascimento CWA, Amarasiriwardena D, Xing BS, 2006. Comparison of natural organic acids and synthetic chelates at enhancing phytoextraction of metals from a multi-metal contaminated soil. Environ. Pollut. 140:114-23.

Ebbs SD, Kochian L, 1998. Phytoextraction of zinc by oat (Avena sativa), barley (Hordeum vulgare) and Indian mustard (Brassica juncea). Environ. Sci. Technol. 32:802-6.

Ekvall L, Greger M, 2003. Effects of environmental biomass-producing factors on Cd uptake in two Swedish ecotypes of Pinus sylvestris. Environ. Pollut. 121:401-11.

Ensley BD, 2000. Rationale for use of phytoremediation. In: I. Raskin, B.D. Ensley (eds.) Phytoremediation of toxic metals e using plants to clean up the environment. John Wiley \& Sons, New York, NY, USA, pp 3-11.

Fagnano M, Adamo P, Zampella M, Fiorentino N, 2011. Environmental and agronomic impact of fertilization with composted organic fraction from municipal solid waste: a case study in the region of Naples, Italy. Agric. Ecosyst. Environ. 141:100-7.

Fendorf SE, 1995. Surface reactions of chromium in soils and waters. Geoderma 67:55-71.

Feng MH, Shan XQ, Zhang S, Wen B, 2005. A comparison of the rhizosphere-based method with DTPA, EDTA, CaCl2, and NaNO3 extraction methods for prediction of bioavailability of metals in soil to barley. Environ. Pollut. 137:231-40.

Fornes F, García-de-la-Fuente R, Belda RM, Abad M, 2009. 'Alperujo' compost amendment of contaminated calcareous and acidic soils: Effects on growth and trace element uptake by five Brassica species. Bioresour. Technol. 100:3982-90.

Garau G, Castaldi P, Santona L, Deiana P, Melis P, 2007. Influence of red mud, zeolite and lime on heavy metal immobilization, culturable heterotrophic microbial populations and enzyme activities in a 
contaminated soil. Geoderma 142:47-57.

Giller K, Bitter E, McGrath P, 1998. Toxicity of heavy metals to microorganisms and microbial processes in agricultural soils: a review. Soil Biol. Biochem. 30:1389-414.

Glaser K, Hackl E, Inselsbacher E, Strauss J, Wanek W, ZechmeisterBoltenstern S, Sessitsch A, 2010. Dynamics of ammonia-oxidizing communities in barley-planted bulk soil and rhizosphere following nitrate and ammonium fertilizer amendment. FEMS Microbiol. Ecol. 74:575-91.

Glass DJ, 1998. The 1998 United States market for phytoremediation. D. Glass Associates, Needham, MA, USA.

Guo ZH, Miao XF, 2010. Growth changes and tissues anatomical characteristics of Giant reed (Arundo donax L.) in soil contaminated with arsenic, cadmium and lead. J. Centr. South Univ. Technol. 17:770-7.

Hargreaves PR, Brookes PC, Ross GJS, Poulton PR, 2003. Evaluating soil microbial biomass carbon as an indicator of long-term environmental change. Soil Biol. Biochem. 35:401-7.

Harman GE, Howell CR, Viterbo A, Chet I, Lorito M, 2004. Trichoderma species- opportunistic, avirulent plant symbionts. Nature Rev. Microbiol. 2:43-56.

Herman DJ, Johnson KK, Jaeger CH, Schwartz E, Firestone MK, 2006. Root influence on nitrogen mineralization and nitrification in Avena barbata rhizosphere soil. Soil Sci. Soc. Am. J. 70:1504-11.

Hernández-Allica J, Becerril JM, Garbisu C, 2008. Assessment of the phytoextraction potential of high biomass crop plants. Environ. Pollut. 152:32-40.

Hu Z, Chandran K, Grasso D, Smets BF, 2002. Effect of nickel and cadmium speciation on nitrification inhibition. Environ. Sci. Technol. 36:3074-8.

Hulzebos EM, Adema DMM, Dir Ven-Van Breemen EM, Henzen L, Van Dis WA, Herbold HA, Hoekstra JA, Baerselman R, Van Gestel CAM, 1993. Phytotoxicity studies with Lactuca sativa in soil and nutrient solution. Environ. Toxicol. Chem. 69:1079-94.

Kapoor A, Viraraghavan T, Cullimore DR, 1999. Removal of heavy metals using the fungus Aspergillus niger. Bioresour. Technol. 70:95-104.

Kelly JJ, Häggblom MM, Tate RL, 2003. Effects of heavy metal contamination and remediation on soil microbial communities in the vicinity of a zinc smelter as indicated by analysis of microbial community phospholipid fatty acid profiles. Biol. Fertil. Soils 38:65-71.

Krämer U, 2005. Phytoremediation: novel approaches to cleaning up polluted soils. Curr. Opin. Biotechnol. 16:133-41.

Lado LR, Hengl T, Reuter HI, 2008. Heavy metals in European soils: a geostatistical analysis of the FOREGS Geochemical database. Geoderma 148:189-99.

Leita L, De Nobili M, Muhlbachova G, Mondini C, Marchiol L, Zerbi G, 1995. Bioavailability and effects of heavy metals on soil microbial biomass survival during laboratory incubation. Biol. Fertil. Soils 19:103-8.

Lievens C, Yperman J, Vangronsveld J, Carleer R, 2008. Study of the potential valorisation of heavy metal contaminated biomass via phytoremediation by fast pyrolysis: Part I. Influence of temperature, biomass species and solid heat carrier on the behaviour of heavy metals. Fuel 87:1894-905.

Lindsay WL, Norvell WA, 1978. Development of a DTPA soil test for zinc, iron, manganese, and copper. Soil Sci. Soc. Am. J. 42:421-8.

Marchiol L, Fellet G, 2011 Agronomy towards the Green Economy. Optimization of metal phytoextraction. Ital. J. Agron. 6:e30.

Mattina MJI, Lannucci-Berger W, Musante C, White JC, 2003. Concurrent plant uptake of heavy metals and persistent organic pollutants from soil. Environ. Pollut. 124:375-8.

Mavrogianopoulos G, Vogli V, Kritsis S, 2002. Use of wastewater as a nutrient solution in a closed gravel hydroponic culture of Giant reed (Arundo donax). Bioresour. Technol. 82:103-7.

McGrath SP, Lombi E, Gray CW, Caille N, Dunham SJ, Zhao FJ, 2006. Field evaluation of $\mathrm{Cd}$ and $\mathrm{Zn}$ phytoextraction potential by the hyperaccumulators Thlaspi caerulescens and Arabidopsis halleri. Environ. Pollut. 141:115-25.

Meers E, Du Laing G, Unamuno V, Ruttens A, Vangronsveld J, Tack FMG, Verloo MG, 2007. Comparison of cadmium extractability from soils by commonly used single extraction protocols. Geoderma 141:247-59.

Meers E, Ruttens A, Hopgood MJ, Samson D, Tack FMG, 2005. Comparison of EDTA and EDDS as potential soil amendments for enhanced phytoextraction of heavy metals. Chemosphere 58:101122.

Mirza N, Mahmood Q, Pervez A, Ahmad R, Farooq R, Shah MM, Azim MR, 2010. Phytoremediation potential of Arundo donax in arsenic-contaminated synthetic wastewater. Bioresour. Technol. 101:5815-9.

Nassi o Di Nasso N, Roncucci N, Triana F, Tozzini C, Bonari E, 2011. Seasonal nutrient dynamics and biomass quality of giant reed (Arundo donax L.) and miscanthus (Miscanthus $\times$ giganteus Greef et Deuter) as energy crops. Ital. J Agron. 6:e24.

Papazoglou EG, 2007. Arundo donax L. stress tolerance under irrigation with heavy metal aqueous solutions. Desalination 211:304-13.

Park Y, Doherty WOS, Halleya PJ, 2008. Developing lignin-based resin coatings and composites. Industr. Crops Prod. 27:163-7.

Pepe 0, Ventorino V, Blaiotta G, 2013. Dynamic of functional groups during mesophilic composting of agro-industrial wastes and freeliving (N2)-fixing bacteria application. Waste Manage. 33:1616-25.

Piccolo A, Nardi S, Concheri G, 1996. Macromolecular changes of soil humic substances induced by interaction with organic acids. Eur. J. Soil Sci. 47:319-28.

Piccolo A, Spaccini R, Nieder R, Richter J, 2004. Sequestration of a biologically labile organic carbon in soils by humified organic matter. Climat. Change 67:329-43.

Piccolo RSJ, Santos F, Frollini E, 1997. Sugar cane bagasse lignin in resol-type resin: alternative application for ligninphenol-formaldehyde resins. J. Macromol. Sci A 34:153-64.

Piotrowska-Seget Z, Cycon M, Kozdrój J, 2005. Metal-tolerant bacteria occurring in heavily polluted soil and mine spoil. Appl. Soil Ecol. 28:237-46.

Pirozzi D, Yousuf A, Fagnano M, Mori M, Fiorentino N, Impagliazzo A, 2010. Lipids production by yeast grown on giant reed biomass. J. Biotechnol. 150:167-8.

Santibáñez C, Verdugo C, Ginocchio R, 2008. Phytostabilization of copper mine tailings with biosolids: implications for metal uptake and productivity of Lolium perenne. Sci. Total Environ. 395:1-10.

Shaheen SM, 2009. Sorption and lability of cadmium and lead in different soils from Egypt and Greece. Geoderma 153:61-8.

Stanier RY, Palleron NJ, Doudorof M, 1966. Aerobic Pseudomonads - a taxonomic study. J. General Microbiol. 43:159-271.

Stewart MA, Jardine PM, Barnett MO, Mehlhorn TL, Hyder LK, McKay LD, 2003. Influence of soil geochemical and physical properties on the sorption and bioaccessibility of chromium (III). J. Environ. Qual. 32:129-37.

Sørensen J, Sessitsch A, 2007. Plant-associated bacteria - lifestyle and molecular interaction. In: J.D. Van Elsas, J.K. Jansson, J.T. Trevors (eds) Modern soil microbiology, 2nd ed. CRC Press, Taylor and Francis Group, New York, NY, USA, pp 211-236.

Van Nevel L, Mertens J, Oorts K, Verheyen K, 2007. Phytoremediation of metals from soils: how far from practice? Environ. Pollut. 150:34-40.

Vervaeke P, Tack FMG, Navez F, Martin J, Verloo MG, Lust N, 2006. Fate of heavy metals during fixed bed downdraft gasification of willow wood harvested from contaminated sites. Biomass Bioener. 30:58-65.

Ververis C, Georghiou K, Christodoulakis N, Santas P, Santas R, 2004. 
Fiber dimensions, lignin and cellulose content of various plant materials and their suitability for paper production. Industr. Crops Prod. 19:245-54.

Vinale F, Abadi K, Ruocco M, Marra R, Scala F, Zoina A, Woo SL, Lorito M, 2003. Remediation of pollution by using biological systems based on beneficial plant-microorganisms interactions. J. Plant Pathol. 85:301.

Vinale F, Aloj V, Pepe 0, Woo SL, Marra R, Ruocco M, Lanzuise S, Scala F, Ritieni A, Cavallo P, Lorito M, 2009. Beneficial microbes useful for biocontrol of plant pathogens and bioremediation of site contaminated by methyl tert-butyl ether. VI-50, page 231 in Proc. 15th Italian Phytopathological Society Congress (SIPaV), Locorotondo (BA), Italy.

Yang Y, Nan Z, Zhao Z, Wang S, Wang Z, Wang X, 2011. Chemical fractionations and bioavailability of cadmium and zinc to cole (Brassica campestris L.) grown in the multi-metals contaminated oasis soil, northwest of China. J. Environ. Sci. 23:275-81.
Wang B, Liu L, Gao Y, Chen J, 2009. Improved phytoremediation of oilseed rape (Brassica napus) by Trichoderma mutant constructed by restriction enzyme-mediated integration (REMI) in cadmium polluted soil. Chemosphere 74:1400-3.

Williams C, Biswas T, 2010. Commercial potential of giant reed for pulp, paper and biofuel production. Rural Industries Research and Development Corp., Kingston ACT, Australia.

Windham MT, Elad Y, Baker R, 1986. A mechanism for increased plant growth induced by Trichoderma spp. Phytopathology 76:518-21.

Wu CH, Wood TK, Mulchandani A, Chen W, 2006. Engineering plantmicrobe symbiosis for rhizoremediation of heavy metals. Appl. Environ. Microbiol. 72:1129-34.

Wu Y, Zhang SZ, Guo XY, Huang HL, 2008. Adsorption of chromium(III) on lignin. Bioresour. Technol. 99:7709-15.

Zafar S, Aqil F, Ahmad I, 2007. Metal tolerance and biosorption potential of filamentous fungi isolated from metal contaminated agricultural soil. Bioresour. Technol. 98:2557-61. 